This is an electronic reprint of the original article. This reprint may differ from the original in pagination and typographic detail.

Author(s): Meriläinen, Niina; Vos, Marita

Title: $\quad$ Framing by Actors in the Human Rights Debate: the Kony 2012 Campaign

Year: $\quad 2014$

Version:

Please cite the original version:

Meriläinen, N., \& Vos, M. (2014). Framing by Actors in the Human Rights Debate: the Kony 2012 Campaign. Nordic Journal of Human Rights, 32(3), 238-257. https://doi.org/10.1080/18918131.2014.937213

All material supplied via JYX is protected by copyright and other intellectual property rights, and duplication or sale of all or part of any of the repository collections is not permitted, except that material may be duplicated by you for your research use or educational purposes in electronic or print form. You must obtain permission for any other use. Electronic or print copies may not be offered, whether for sale or otherwise to anyone who is not an authorised user. 


\title{
Framing by Actors in the Human Rights Debate: the Kony 2012 Campaign
}

Niina Meriläinen and Marita Vos, University of Jyväskylä, Finland

\begin{abstract}
Human rights actors form networks and debate in issue arenas to find solutions to violations. Framing can be used to create and increase issue salience as well as organisational importance, thus influencing power relations and the human rights debate. Not all the actors are equally powerful, meaning that the more dominant actors function as gatekeepers, controlling the debate and the subsequent decision-making process. The campaign Kony 2012 by Invisible Children (IC) is used as a case study to see whether, by observing the reaction the campaign elicited from two well-established gatekeepers (Amnesty International and Human Rights Watch), this campaign by a previously relatively unknown non-governmental organisation (NGO) had affects on issue salience and on the power relations between human rights NGOs. The findings show that IC was able to generate a buzz with its Kony 2012 campaign. It was able momentarily to influence power relations by producing new ideas and content. Notwithstanding, the two established actors, however, were quick to maintain their power positions as gatekeepers, an issue much discussed by Bob and Carpenter. Although as a result the existing power relations remained unchanged at the end of the monitoring period, this case study shows that social media may lower the threshold for new actors, supporting Barzilai-Nahon's notion of the power of less central actors in networks.
\end{abstract}

Keywords: Framing; Gatekeeper Theory; Power Relations; Non-governmental Organisations 


\section{Introduction}

Human rights issues have largely been covered in the academic literature over the last decades by focusing on the role of different actors, such as non-governmental organisations (NGOs), multinationals, states and individuals with influence on human rights performance. Much debate has been on the power relations between actors in the human rights networks. As Keck and Sikkink argue, NGOs operate in networks. ${ }^{1}$ However, not all actors have the same power in the debate: for example some are able to act as gatekeepers while other, less central actors ${ }^{2}$ have less influence on what issues are debated and how. This affects the context in the issues debated and subsequently the decision-making process concerning policies to tackle violations.

This article focuses on the power relations between the two central gatekeepers in the human rights arena, Amnesty International (Amnesty) and Human Rights Watch (HRW), and a new actor, Invisible Children (IC), through an online case study. An online case study was chosen because IC’s Kony 2012 campaign was instigated online using the video streaming services YouTube and Vimeo, with additional multiplatform support from IC's main website and Facebook page, as well as its Twitter account. The responses of Amnesty and HRW were found on their main websites, since many organisations such as NGOs use their main websites to disseminate official information to large international publics. ${ }^{3}$

The research questions are: (RQ1) How did the gatekeeper NGOs, Amnesty and HRW, react to the new actor, IC? (RQ2) Did IC's Kony campaign affect the existing power relations in the NGO network? To answer these research questions, the response of Amnesty and HRW to IC and its Kony 2012 campaign is analysed. During an 18-week research period, content related to IC and the Kony 2012 campaign, along with all related content in the news sections of the websites of both gatekeeper NGOs, was monitored and a textual analysis of the related posts, totalling 24 altogether, conducted.

Before clarifying the method of analysis used and presenting the findings, insights from the literature on issues arenas, gatekeeper theory and framing are discussed. The influential work of Keck and Sikkink ${ }^{4}$ shows that human rights NGOs operate in networks. This article discusses the interplay of three actors in one such network. Issue

\footnotetext{
1 ME Keck and K Sikkink, Activists Beyond Borders: Advocacy Networks in International Politics (Ithaca, NY: Cornell University Press, 1998).

2 K Barzilai-Nahon, “Toward a Theory of Network Gatekeeping: A Framework for Exploring Information Control” (2008) 59

J of American Society for Info Sci \& Tech 1493-1512.

3 Meriläinen \& Vos, “Human Rights Organizations and Online Agenda Setting” (2011) 16 Corporate Communications, an Int J 293-310.

4 ME Keck and K Sikkink, Activists Beyond Borders: Advocacy Networks in International Politics (Ithaca, NY: Cornell University Press, 1998).
} 
arena theory is used to clarify the communication context in the network. ${ }^{5}$ Gatekeeper theory is also drawn on, building on the insights of $\mathrm{Bob}^{6}$ and Carpenter ${ }^{7}$ on the roles of different actors in a debate and, in particular, the role of the dominant actors that function as gatekeepers. Addtionally, insights from Barzilai-Nahon ${ }^{8}$ on the possibility of changes in power relations are also used. Framing theory is drawn on to clarify how actors present other actors or issues. Framing refers to providing a context for understanding an issue in a particular way, and often goes together with choosing a specific angle to emphasise certain aspects of the issue. According to Entman, ${ }^{9}$ the purpose of framing is "to select some aspects of a perceived reality and make them more salient in a communicating text, in such a way as to promote a particular problem definition, causal interpretation, moral evaluation, and/or treatment recommendation". Framing is often used to increase the salience of a societal issue and draw attention to it in order to facilitate problem solving. It is only when an issue is seen as salient by the actors that it will attract enough attention to be discussed.

\section{Issue Arenas and Network Power Relations}

Human rights issues are topical agendas that are discussed in multiple issue arenas. Agendas are clusters of multiple issues formed by the actors who frame them. Issues become topical when there is debate about them by at least two actors. These actors can be individual people, states, organizations, NGOs or other groups. An issue exists when an action takes place based on the public's shared interpretations of events and/or actions in their environment. ${ }^{10}$ Thus, an issue may be relevant but its legitimacy will depend on the interest and actions of the actors in the issue arena. Issues are discussed in issue arenas that may be real or virtual platforms, ${ }^{11}$ such as parliaments, social media and organisations' boardrooms.

The actors who discuss and decide topics in issue arenas form networks.

Networks can intertwine, actors can discuss issues on multiple issue arenas and belong to various networks. Lewin ${ }^{12}$ introduced the concept of channels with gatekeepers. He pointed out that channels, referred to as networks in this article, have no simple beginning or end, but are circular in character: they intertwine and one channel can be

5 Vos, Schoemaker \& Luoma-aho, "Setting the Agenda for Research on Issue Arenas”, (2014) 19 Corporate Communications, an Int J. 200-215 6 C Bob, The International Struggle for New Human Rights (U of Pennsylvania Press: Pennsylvania Studies in Human Rights, 2009).

7 CR Carpenter, “Setting the Advocacy Agenda: Theorizing Issue Emergence and Nonemergence in Transnational Advocacy Networks” (2007) 51 Int Studies Quarterly 99-120.

8 K Barzilai-Nahon, “Toward a Theory of Network Gatekeeping: A Framework for Exploring Information Control” (2008) 59 J of American Society for Info Sci \& Tech 1493-1512.

9 RM Entman, “Framing: Toward Clarification of a Fractured Paradigm”(1993) 43 J of Communication 51-58, 52. 10 CH Botan \& M Taylor, “Public Relations: State of the Field” (2004) 54 J of Communication 645-661.

11 Luoma-aho \& Vos, “Towards a More Dynamic Stakeholder Model: The Role of Issue Arenas for Corporate Reputation” (2010) 15 Corporate Communication, an Int J 315-331.

12 K Lewin, “Frontiers in Group Dynamics. II Channels of Group Life; Social Planning and Action Research” (1947) 1(2) Human Relations, 143-153. 
part of another. Castells ${ }^{13}$ defines networks as sets of interconnected nodes that may have varying relevance to the networks they form. Keck and Sikkink ${ }^{14}$ studied NGO advocacy networks and concluded that

networks are forms of organization characterized by voluntary, shared, and horizontal patterns of communication exchange ... The network concept travels well because it stresses fluid and open relations among committed and knowledgeable actors working in specialized issue areas. We call them advocacy networks because advocates plead the causes of others or defend a cause or proposition.

Additionally, Hudson ${ }^{15}$ holds that relationships are the building-blocks of networks and are balanced as well as prioritised on the basis of values. Lin $^{16}$ added that individuals engage in interactions and networking in order to produce profits, which can be a better position in the network, the ability to set agendas and credibility and legitimacy, which in turn impact actors' overall power position. Similarly, Yanacopulos ${ }^{17}$ added that resources, such as funding, legitimacy and information, all have an impact on NGO networks.

Actors have power to varying degrees in the network as "power relationships are asymmetrical actual or potential interactions among social actors that enable one actor to exert greater control over another's behaviour". ${ }^{18}$ According to Pettigrew, ${ }^{19}$ a "power relation is a causal relation between the preferences of an actor regarding an outcome and the outcome itself ... It involves the ability of an actor to produce outcomes consonant with his perceived interests.” As multiple actors with similar or different interests are involved, there may be competition and alliance-forming within the network, also including power play. As Pallas and Urpelainen ${ }^{20}$ argue, "in the absence of consensus, power becomes a key issue”. Power relations exist between gatekeepers with a central position in the network and less central actors. Although a comprehensive debate on power is beyond the scope of this article, it is important to acknowledge the role of power relations in issue arena debates. Thus, to better understand the reality of power relations inside networks, gatekeeper theory is also utilised.

13 M Castells, Communication Power (New York: Oxford UP, 2009).

14 ME Keck \& K Sikkink, Activists Beyond Borders: Advocacy Networks in International Politics (Ithaca, NY: Cornell UP, 1998).

15 A Hudson, “NGOs’ Transnational Advocacy Networks: From ‘Legitimacy’ to ‘Political Responsibility’?“ (2001) 1 Global Networks 331-

352.

16 N Lin, “Building a Network Theory of Social Capital” (1999) 22 Connections 28-51.

17 H Yanacopulos, “The Strategies that Bind: NGO Coalitions and their Influence” (2005) 5 Global Networks 93-110.

18 D Knoke, “Networks of Elite Structures and Decision Making” (1993) 22 Sociological Methods \& Research 23-45, 24.

19 AM Pettigrew, “Information Control as a Power Source” (1972) 6 Sociology 187-204, (p. 188).

20 CL Pallas \& J Urpelainen, “Mission and Interests: The Strategic Formation and Function of North-South NGO Campaigns” (2013) 19 Global

Governance: A Rev of Multilateralism \& Int Orgs 401-423, 405. 


\section{Gatekeepers and Less-Central Actors}

Not all actors in a debate will have the same power. This in turn will influence the debate as some actors will be able to act as gatekeepers and some will be less central. ${ }^{21}$ An actor who has power and uses it to steer a debate can influence understanding of the issues discussed and the context in which they are debated. This influences subsequent decision-making as some issue connections and contexts may be left out of the debate. Also actors, who present alternative viewpoints, may also be left out of the debate as a result. Gatekeepers often have the power to decide the dominant frames and push and pull issues in the issue arena. Lewin ${ }^{22}$ was among the first to point out the gatekeeping role in various arenas of actors who were able to make decisions on salience. The more well-known human rights NGOs function as leaders in human rights debates. Carpenter ${ }^{23}$ and $\mathrm{Bob}^{24}$ refer to them as gatekeepers who use power. ${ }^{25}$ Erickson Nepstad and Bob ${ }^{26}$ also discuss the importance of such leaders in social movements.

The central hub theory explains that gatekeeper actors form a central hub, meaning that they form the decision-making centre of the network. They have the ability and means to lend visibility to issues. ${ }^{27}$ In various networks where human rights are debated, NGOs are the central actors. Depending on their size and resources, human rights NGOs promote activism, conduct research, report abuses, and develop proposals for new human rights laws. ${ }^{28}$ They define problems, create solutions and politicise issues, and thrive on mobilising structures outside established institutions. ${ }^{29}$ Whereas HRW focuses on investigating, reporting and influencing policy decision-makers, Amnesty's biggest roles involve investigating and creating activism at the grassroots level. ${ }^{30}$ According to an article written by the executive director of Human Rights Watch, Kenneth Roth, the strength of NGOs such as HRW is their ability to investigate

21 K Barzilai-Nahon, “Toward a Theory of Network Gatekeeping: A Framework for Exploring Information Control” (2008) 59 J of American Society for Info Sci \& Tech 1493-1512.

22 K Lewin, “Frontiers in Group Dynamics. II Channels of Group Life; Social Planning and Action Research” (1947) 1(2) Human Relations, $143-153$.

23 CR Carpenter, “Setting the Advocacy Agenda: Theorizing Issue Emergence and Nonemergence in Transnational Advocacy Networks” (2007) 51 Int Studies Quarterly 99-120.

24 Bob, The International Struggle for New Human Rights (U of Pennsylvania Press: Pennsylvania Studies in Human Rights, 2009).

25 CR Carpenter, “Vetting the Advocacy Agenda: Network Centrality and the Paradox of Weapons Norms” (2011) 65 International Organization 69-102.

26 S Erickson Nepstad \& C Bob, “When do Leaders Matter? Hypotheses on Leadership Dynamics in Social Movements” (2006) 11

Mobilization: An International Quarterly 1-22.

27 C Bob, The International Struggle for New Human Rights (U of Pennsylvania Press: Pennsylvania Studies in Human Rights, 2009).

28 See K Martens, “Mission Impossible? Defining Nongovernmental Organizations” (2002) 13 Voluntas: Int J of Voluntary \& Nonprofit

Organisations 271-285; Meriläinen \& Vos, “Human Rights Organizations and Online Agenda Setting” (2011) 16 Corporate Communications, an

Int J 293.; D Davis, A Murdie \& C Garnett Steinmetz, ““Makers and Shapers”: Human Rights INGOs and Public Opinion” (2012) 34 Human

Rights Quarterly 199-224.

29 J Joachim, “Framing Issues and Seizing Opportunities: Women‘s Rights and the UN” (2003) 47 Int Studies Quarterly $247-274$.

30 Meriläinen \& Vos, “Human Rights Organizations and Online Agenda Setting” (2011) 16 Corporate Communications, an Int J 293-310;

Meriläinen \& Vos, “Framing Issues in the Public Debate: The Case of Human Rights” (2013) 18 Corporate Communications: an Int J 119-134. 
possible human rights violations and assign blame in order to shame violators. ${ }^{31}$ Roth claims that this core task of human rights NGOs works best when it is clear what the violation, perpetrator, and solution are. Naming and shaming are core activities of human rights NGOs. NGOs are needed to garner a response from large groups of people, as deteriorating human rights situations alone are not enough to convince the public to believe that rights are being violated. ${ }^{32}$

Although consensus may sometimes be negotiated and found, and even gatekeeper status accepted by non-gatekeepers, in a situation where many actors in the network are participating in a debate, competition may well arise, including in human rights networks. In the competition over issues and frames, power over information ends up in the hands of those who can edit and credibly validate messages to communicate what is salient and correct. The ability to do this is a power resource of gatekeepers. ${ }^{33}$ These main actors control the debate and accept frames. By wielding their power over communication, gatekeepers in the central hub can intentionally keep certain issues or points of view out of the debate or even prevent actors with special interests from participating and promote only agendas favourable to their own interests. ${ }^{34}$

The above suggests a rather stable network situation. The distribution of position, resources and power between actors undeniably determines which actors get to set the network agenda. ${ }^{35}$ However, power is not only a matter of who possesses it, but also of control over resources and the skill with which it is used. ${ }^{36}$ In issue arenas, the power struggle is unceasing. If an actor is not able to utilise a position of power, then more skilful actors may take over and discredit the less capable actor. Therefore, neither a particular actor's power nor the actors that form the central hubs in the networks are stable entities. Power relations and central hubs can be affected by framing, which can change the debate and, subsequently, the outcome. Outcomes can vary from opinions or behavioural changes among the public though new domestic policies to international laws over human rights. In power relations, the focus should not be on the gatekeepers alone but also on the less central actors. Barzilai-Nahon states that the less central, the gated, can have power in relation to gatekeepers if they exhibit a combination of four attributes: political power in relation to the gatekeeper(s), the ability to produce information, a relationship with the gatekeeper(s), and alternatives to the

31 K Roth, “Defending Economic, Social and Cultural Rights: Practical Issues Faced by an International Human Rights Organization” (2004) 26 Human Rights Quarterly 63-73.

32 D Davis, A Murdie \& C Garnett Steinmetz, “““Makers and Shapers”: Human Rights INGOs and Public Opinion” (2012) 34 Human Rights Quarterly 199-224.

33 RO Keohane \& JS Nye Jr, “Power and Interdependence in the Information Age” (1998) 77 Foreign Affairs 81-94.

34 See P Bachrach \& MS Baratz, “Two Faces of Power” (1962) 56 American Pol Sci Rev 947-952; JH Rowbottom, “Media Freedom and

Political Debate in the Digital Era” (2006) 69 Modern Law Rev 489-513; A Anton, “Socialist Voices”, in A Anton \& R Schmitt (eds), Toward a New Socialism (Plymouth: Lexington Books, 2007), 21-52.

35 LW Bennett, K Foot \& M Xenos, “Narratives and Network Organization: A Comparison of Fair Trade Systems in Two Nations” (2011) 61 J of Communication 219-245.

36 AM Pettigrew, “Information Control as a Power Source” (1972) 6 Sociology 187-204, 188. 
gatekeeper(s). ${ }^{37}$ Thus, by means of content production, control of agendas and frames, relationship-building and producing alternatives to the debate, the less-central can change the course of the debate and influence power relations. Moreover, fragmentation and tension within the network can lead actors to form competing networks and alliances ${ }^{38}$ with their own central hubs, which can then challenge the original central hub and power relations in the network and issue arena.

Clearly, power is more than just Dahl's notion of A statically having influence over B. ${ }^{39}$ Moreover, debates do not take place in only one issue arena. The position and salience of gatekeepers, the less central actors, issues and arenas are constantly in flux. Having resources or belonging to a central hub can be a sign of power, and thus confer a position as a central actor. Yet power relations can also be influenced by studying and understanding the actors in issue arenas and their strategic framing and communication practices. Furthermore, new alliances can be formed to take on the central hubs. A wider perspective on power and framing can provide a better understanding of issue adoption processes and power relations in the arenas of human rights issues.

Additionally, the selective nature of framing in network relations should be addressed, given that this influences the debate and subsequent decision-making.

\section{Framing and Selective Realities in Networks}

Framing can hardly be avoided, as any storyline results in emphasising some matters above others. However, it is often done with a purpose, as a thought process with strategic functions and aims. Different actors use different framing models to further their own agendas. ${ }^{40}$ New frames can also be created by real-world events like the Arab Spring or oil disasters. Independent actors can successfully push their frames into several arenas and gain credibility for their views if events are favourable and frames by other actors are seen as unreliable or propagandist. ${ }^{41}$ Indeed, circumstances can make issues salient and create new frames which actors must then address.

Framing involves not only justifying one's own stand on issues but also elements of guidance and education. Druckman mentions that "Framing effects may occur, not because elites seek to manipulate citizens, but rather because citizens delegate to credible elites for guidance". ${ }^{42}$ He adds that the public then chooses which frames to accept and hence that this is not manipulation but guidance. ${ }^{43}$ However, if other actors

\footnotetext{
37 K Barzilai-Nahon, “Toward a Theory of Network Gatekeeping: A Framework for Exploring Information Control” (2008) 59 J of American Society for Info Sci \& Tech 1493-1512.

38 LW Bennett, K Foot \& M Xenos, “Narratives and Network Organization: A Comparison of Fair Trade Systems in Two Nations” (2011) 61 J of Communication $219-245$. 39 Robert Dahl, “The Concept of Power” (1957) 2 Behav Sci 201-215.

40 C Roggeband \& R Vliegenthart, “Divergent Framing: The Public Debate on Migration in the Dutch Parliament and Media 1995-2004” (2007) 30 West European Politics 524-548; JW Busby, “Bono Made Jesse Helms Cry: Jubilee 2000, Debt Relief, and Moral Action in International Politics” (2007) 51 Int Studies Quarterly 247-275.

41 N Hamdy \& EH Gomaa, “Framing the Egyptian Uprising in Arabic Language Newspapers and Social Media” (2012) 62 J of Communication 195-211.

42 JN Druckman, “On the Limits of Framing Effects: Who Can Frame?” (2001) 63 J of Politics 1041- 1066, 1061.

43 JN Druckman, “On the Limits of Framing Effects: Who Can Frame?” (2001) 63 J of Politics 1041-1066, 1061.
} 
or the general public do not share the values promoted by the frames, then there can be no consensus about their importance.

Values are essential motivational beliefs about outcomes or favourable modes of individual behaviour. ${ }^{44}$ As such, they are a key aspect of framing. ${ }^{45}$ A value frame connects issues and values. ${ }^{46}$ Framing may be unsuccessful if actors do not share the value set or accept a new value frame. ${ }^{47}$ For example, some organisations may intentionally discredit frames by human rights actors by opposing them with security or fear frames, in which case the actors must reframe the myths of fear and anxiety in terms of fact and truth. ${ }^{48}$ Moreover, using bandwagon framing - where multiple frames are combined ${ }^{49}$ - can lead to the issue gaining new salience. An example of this is combining human rights frames with environmental protection frames in order to gain attention for the latter, much as suggested by Nicholson and Chong. ${ }^{50}$

Every issue arena will contain multiple frames and issues, but only a few can be relevant at one and the same time. Social issues, such as human rights issues, do not operate independently. Earlier, Winter and Eyal argued that social issues can only remain relevant for from four to six weeks. ${ }^{51}$ The issue attention cycle by Downs comprises five evolutionary stages, starting with the pre-problem stage, moving to the euphoric stage, realisation of costs stage, the decline stage and finally to the post-stage, where they are replaced by new issues. ${ }^{52}$ Hilgartner and Bosk ${ }^{53}$ criticised Downs' model for not taking into account competing issues, since issues and frames compete with each other for the attention of decision-makers and citizens. The critique is valid, given the dynamic nature of debates in issue arenas, illustrating the power of frames and the competition between them. Additionally social media and the Internet, such as NGO websites, have also influenced the ways in which issues can emerge and become topical. $^{54}$ As multiple actors, their issues and frames compete for attention, power relations in the issue arena are sustained and re-examined.

44 WH Kilburn, “Personal Values and Public Opinion” (2009) 90 Soc Sci Quarterly 868-885.

45 Meriläinen \& Vos , “Framing Issues in the Public Debate: The Case of Human Rights” (2013) 18 Corporate Communications: an Int J 119134.

46 PR Brewer \& K Gross, “Values, Framing and Citizens’ Thoughts about Policy Issues: Effects on Content and Quantity” (2005) 26 Pol Psych 929-948.

47 D Chong \& JN Druckman, “Framing Theory” (2007) 10 Annual Rev of Pol Sci 103-126.

48 ML Cook, “The Advocate’s Dilemma: Framing Migrant Rights in National Settings” (2010) 4 Stud in Soc Justice $145-164$.

49 S Nicholson \& D Chong, “Jumping on the Human Rights Bandwagon: How Rights-based Linkages Can Refocus Climate Politics” (2011) 11 Global Env Pol 121-136.

50 S Nicholson \& D Chong, “Jumping on the Human Rights Bandwagon: How Rights-based Linkages Can Refocus Climate Politics” (2011) 11 Global Env Pol 121-136.

51 JP Winter \& CH Eyal, “Agenda Setting for the Civil Rights Issue” (1981) 45 Public Opinion Quarterly $376-383$.

52 A Downs, “Up and Down with Ecology - The 'Issue Attention Cycle”” (1972) 28 Public Interest 38-50.

53 S Hilgartner \& CL Bosk, “The Rise and Fall of Social Problems: A Public Arenas Model” (1988) 94 American J of Soc 53-78.

54 Meriläinen \& Vos, “Human Rights Organizations and Online Agenda Setting” (2011) 16 Corporate Communications, an Int J 293-310; Meriläinen \& Vos, "Framing Issues in the Public Debate: The Case of Human Rights” (2013) 18 Corporate Communications: an Int J 119-134. 
In human rights issue arenas, multiple actors with different information and expertise battle to change policies, making agenda-setting challenging in an international context. ${ }^{55}$

Framing by multiple actors can be successful, not only in reaching public groups on human rights issues, ${ }^{56}$ but also in influencing power relations. Without the power and credibility it brings, actors cannot persuade others to perceive new frames and issues as salient. For the most part, only powerful gatekeepers can influence the debate in issue arenas. Thus, it is essential to examine how and which actors participate in an issue arena and the power relations that subsist between them.

The situation of having many NGOs working in the same issue arenas creates competition between the actors over power and position. Human rights NGOs see the network, themselves and other actors differently, according to their own position in the network. ${ }^{57}$ Selectivity is a part of power relations and thus part of the debates on human rights issues. Power positions can influence which issues are promoted and with whom actors co-operate. Powerful human rights actors are selective in their operations and framing, and well-established, often northern, NGOs, are selective in choosing their southern partners. ${ }^{58}$

Human rights networks consist primarily of a few key actors with whom newer NGOs try to link themselves. ${ }^{59}$ An established NGO may co-operate with a new one which shares its own agenda, or generates some benefit such as grassroots participation for successful campaign outcomes. ${ }^{60}$ Pallas, Fletcher and Han state that if human rights NGOs and their actions were wholly based on morals and unselfishness, they would consistently go after the worst human rights offenders. ${ }^{61}$ This is not always the case, however. Anderson and others state that rather than serving as a means for the grassroots movements or the people, NGOs are a vehicle for international elites to talk to other international elites about topics -frequently of undeniably critical importance about which they care. ${ }^{62}$

55 V Haufler, “Governing Corporations in Zones of Conflict: Issues, Actors, and Institutions”, in D Avant \& M Finnemore (eds), Who Governs the Globe? (Cambridge, Cambridge UP 2010), 102-130.

56 Meriläinen \& Vos , “Framing Issues in the Public Debate: The Case of Human Rights” (2013) 18 Corporate Communications: an Int J 119134.

57 DR Davis \& Amanda Murdie, “Looking in the Mirror: Comparing INGO Networks Across Issue Arenas”

<https://courses.cit.cornell.edu/patel/psac/Davis_PSAC_3_9.pdf> Accessed 17 August 2012.

58 C Fleay, “Transnational Activism, Amnesty International and Human Rights in China: The Implications of Consistent Civil and Political Rights Framing” (2011) 16 Int J of Human Rights 915- 930; CL Pallas \& J Urpelainen, “Mission and Interests: The Strategic Formation and Function of North-South NGO Campaigns” (2013) 19 Global Governance: A Rev of Multilateralism \& Int Orgs 401-423, 405.

59 DR Davis \& Amanda Murdie, “Looking in the Mirror: Comparing INGO Networks Across Issue

Arenas” <https://courses.cit.cornell.edu/patel/psac/Davis_PSAC_3_9.pdf> Accessed 17 August 2012.

60 CL Pallas \& J Urpelainen, “Mission and Interests: The Strategic Formation and Function of North-South NGO Campaigns” (2013) 19 Global Governance: A Rev of Multilateralism \& Int Orgs 401-423,

61 CL Pallas, K Fletcher \& B Han “How Do Campaigners Choose Their Targets? Exploring Cost-Benefit Analysis among Nongovernmental Organizations” (2012) Presented at International Studies Association Annual Convention, San Diego, April 1-4.

62 See K Anderson, “The Ottawa Convention Banning Landmines, the Role of International Nongovernmental Organizations and the Idea of International Civil Society” (2000) 11 Eur J of Int Law 91-120; DR Davis \& Amanda Murdie, “Looking in the Mirror: Comparing INGO Networks Across Issue Arenas” <https://courses.cit.cornell.edu/patel/psac/Davis_PSAC_3_9.pdf> Accessed 17 August 2012; CL Pallas, K 
Competition may lead human rights NGOs to choose their priorities based on factors other than human rights alone. Equally important is the notion that NGOs select their campaigns based on a cost-benefit analysis. NGOs estimate and select the possible targets of their advocacy campaigns "on the basis of a cost-benefit analysis, in which NGOs weight the hoped-for level of change in the target's behavior against the resources necessary to undertake attacks on the target”, which supports Semb’s suggestion that states selectively adopt human rights conventions. ${ }^{63}$ This manner of selecting issues and frames may seem brutal, but it is a reality in campaigns by human rights NGOs. A cost-benefit analysis follows the same pattern of zero-sum campaigning, where some issues are promoted and others left without attention, though they may be picked up and brought into issue arenas by other actors. ${ }^{64}$

Debate does not take place without the strategic planning of frames and goals. Actors need intentional framing in issue arenas in order to succeed in their goals. For there to be debate and resolutions on human rights matters, issues need to be framed as salient. Human rights NGOs determine which issues to advocate by assessing multiple factors. Similarly, they assess their position in the network, e.g. by estimating the economic realities of organisational functions, such as amount of staff and financial resources. If this is the case, we need to examine how framing is used in the context of human rights issues and how this affects the relationships between the actors in the human rights debate.

\section{Analysis}

To investigate how the existing gatekeepers respond to a new actor in the human rights network, a case study was conducted online in which the response of two gatekeeper NGOs towards a newer NGO was monitored. The focus was on analysing the possible responses by Amnesty and HRW to IC and its Kony 2012 campaign and, in particular, whether the campaign affected the prevailing power relations in the human rights network. The analysis was carried out by looking at the framing done by the two gatekeepers. Following the previous theorising on gatekeepers, ${ }^{65}$ it is presumed that NGOs operate in networks with gatekeepers and less central actors. The study focused on the responses the IC's campaign received from two well-established human rights

Fletcher \& B Han "How Do Campaigners Choose Their Targets? Exploring Cost-Benefit Analysis among Nongovernmental Organizations" (2012) Presented at International Studies Association Annual Convention, San Diego, April 1-4.

63 CL Pallas, K Fletcher \& B Han "How Do Campaigners Choose Their Targets? Exploring Cost-Benefit Analysis among Nongovernmental Organizations” (2012) Presented at International Studies Association Annual Convention, San Diego, April 1-4, 12; AJ Semb, ”Why (not) Commit? Norway, Sweden and Finland and the ILO Convention 169” (2012) 30 Nordic Journal of Human Rights 122-146.

64 See J-H Zhu, "Issue Competition and Attention Distraction: A Zero-Sum Theory of Agenda-Setting” (1992) 69 Journalism \& Mass Communication Quarterly 825-836; CR Carpenter, "Setting the Advocacy Agenda: Theorizing Issue Emergence and Nonemergence in Transnational Advocacy Networks” (2007) 51 Int Studies Quarterly 99-120; Meriläinen \& Vos, “Framing Issues in the Public Debate: The Case of Human Rights” (2013) 18 Corporate Communications: an Int J 119-134.

65 C Bob, The International Struggle for New Human Rights (U of Pennsylvania Press: Pennsylvania Studies in Human Rights, 2009); CR Carpenter, "Setting the Advocacy Agenda: Theorizing Issue Emergence and Nonemergence in Transnational Advocacy Networks” (2007) 51 Int Studies Quarterly 99-120. 
NGOs, Amnesty and HRW, who were chosen to represent the gatekeepers in this analysis. The responses were monitored by looking at the news sections of websites operated by Amnesty and HRW. Both NGOs utilise a multi-channel strategy to connect internationally with large audiences, communicating about issues via social media sites such as Facebook and Twitter that, in turn, link to their main website for more detailed information consistent with the social media content. ${ }^{66}$

The search was conducted in the News sections of amnesty.org and hrw.org using the search bar and the following keywords: Kony 2012, Joseph Kony, LRA (Lord's Resistance Army), Uganda and Invisible Children. The analysis was limited to posts on the main websites, although posts also appeared in Amnesty and HRW blogs or their other social media pages. As multiplatform strategies are commonly used, identical posts can occur in several places. Where the same text occurred more than once in the sample, it was counted as one post. The posts on the main websites comprised statements, news stories and research reports with long narratives illustrated by photographs and video testimony, and with additional links.

The timeframe for the monitoring was 18 weeks, commencing with the release of the Kony 2012 video on 5 March 2012, and ending on 9 July 2012. This allowed observation of the first reactions of the human rights NGOs and of possible changes in power relations in the weeks following the launch of the campaign by IC. Only posts found on the websites that fitted into the timeframe were considered. The length of the monitoring period and the subsequent analytical procedure were drawn from Winter and Eyal $^{67}$ who argued that social issues, such as human rights issues, only remain relevant for four to six weeks. In the present study, a monitoring period of 18 weeks was chosen to see if the issue investigated would remain salient longer than estimated by Winter and Eyal. ${ }^{68}$ The monitoring period started at campaign launch so as to be able to analyse the responses it elicited from Amnesty and HRW, and how this affected power relations in the human rights network, if at all.

The results of the textual analysis, which are based on the data gained from the monitoring period, is presented. The course of the events is treated in chronological order. For Amnesty, the search produced 10 posts, 8 of them different, in texts that addressed issues related to the Kony 2012 campaign, such as Uganda, warlords and LRA or Joseph Kony, and 7 of which were made between 8 March and 24 May. Compared to Amnesty, HRW, with 16 related posts, 12 of which were made between 9 March and 20 April, was more active. Analysis of the 24 NGO responses was conducted by the researchers. First, each selected post was read carefully, to see if the keywords were present and the post fitted the timeframe. Secondly, for each post a summary of the text was written and included in a Word document, which served as a long data extraction table with the publication dates, titles, web links, and a summary of all the

\footnotetext{
66 Meriläinen \& Vos , “Framing Issues in the Public Debate: The Case of Human Rights” (2013) 18 Corporate Communications: an Int J 119134.

67 JP Winter \& CH Eyal, “Agenda Setting for the Civil Rights Issue” (1981) 45 Public Opinion Quarterly $376-383$.

68 JP Winter \& CH Eyal, “Agenda Setting for the Civil Rights Issue” (1981) 45 Public Opinion Quarterly 376-383.
} 
selected posts. The analysis of the responses focused on how framing was used by Amnesty and HRW, related issues or towards IC were discussed.

In the next section, we attempt to show how IC brought their agenda into the issue arena with the aim of becoming a more well-known actor in the network. The campaign centred on a 30-minute video, titled Kony 2012. Below, IC, the organisation, and the campaign itself, are first briefly introduced. Next, the responses of Amnesty and HRW are reported and, finally, conclusions are drawn.

\section{Invisible Children and Kony 2012}

Invisible Children (IC) is a US-based human rights NGO that became widely known through the Kony 2012 campaign. IC states that they are a group of storytellers, visionaries, humanitarians, artists, and entrepreneurs, working both in Uganda and in the US. ${ }^{69}$

On 5 March 2012, IC released the Kony 2012 video, emphasising the value of cyberactivism, that is, online activism. The video was 30 minutes long and viewable on YouTube and Vimeo, as well as via a link from social media sites like Facebook. The premise of the video was to inform the public about Uganda, the warlord Joseph Kony, and human rights violations practised by Kony’s Lord's Resistant Army (LRA). IC wanted to help the youth of the country catch Joseph Kony and to raise interest in the cause. The tone of the video was energetic and filled with easy catchphrases. IC used value framing to give their agenda salience for, in particular, younger westerners, connecting them to the cause by oversimplifying the issue, leaving the viewer in no doubt as to who the hero and villain are. Naming and shaming framing was used in abundance to ensure that viewers would most likely side with IC. Furthermore, in the video IC framed themselves as credible do-gooders by co-opting the International Criminal Court (ICC) in The Hague, and incorporating an interview with its lead prosecutor. IC also called on youth to engage in the campaign by making donations and by contacting [American] decision-makers and celebrities to gain more publicity and political momentum for the cause. The video mostly showed young people, most likely to frame the topic to better relate to a young audience. According to IC, when confronted by demands for change being made by young people, decision-makers would have to take political action against Joseph Kony and LRA.

With the Kony 2012 campaign, Invisible Children was able to bring an issue into the centre of the issue arena. It became much discussed in social and traditional media. The campaign drew attention to an issue which was well known, violations by warlords, but had not been salient for some time. For many decades, little interest had been shown in the West regarding the conflict in Uganda. IC had helped raise awareness ${ }^{70}$ even before the Kony 2012 video. However, with the Kony 2012 campaign, and by the

69 IC, “Invisible Children” <http://invisiblechildren.com/> Accessed 6 September 2012. 70LL Burges, “Efforts at Peace: Building a United Uganda” (University of Tennessee Honors Thesis Projects) <http://trace.tennessee.edu/utk_chanhonoproj/1157> Accessed 17 August 2012. 70 LL Burges, “Efforts at Peace: Building a United Uganda” (University of Tennessee Honors Thesis Projects)

<http://trace.tennessee.edu/utk_chanhonoproj/1157> Accessed 17 August 2012. 
emphasis throughout the video on both the person of Joseph Kony and the role of IC as a new energetic and youthful NGO, IC was clearly aiming to make both Joseph Kony and their own organisation well-known. While not a new departure in the human rights field, in its style of presentation and simplification the issue was different. Human rights NGOs see themselves as watchdogs for other actors and accordingly promote themselves when they promote an issue. ${ }^{71}$

In the present instance, within the space of a week, the frame chosen led to IC's campaign becoming one of the most topical human rights issues. In fact, the Kony 2012 campaign generated a massive public response.Within the first five days, the video was viewed over 55 million times ${ }^{72}$ and, by 12 July, the Kony 2012 video had been watched on YouTube 91,812,575 times. The campaign and IC were widely discussed online, and the story was frequently picked up internationally by traditional media outlets, such as CNN (USA), the BBC (UK), Reuters (UK), YLE (FIN), the Financial Times (UK), Helsingin Sanomat (FIN), and Der Spiegel (GER). ${ }^{73}$ Due to the enormous popularity of the issue, Amnesty and HRW may have felt compelled to address it, despite it not being a top priority on their agendas. Their reactions lend support to Barzilai-Nahon's ${ }^{74}$ argument that actors outside the central hub can influence gatekeeper actors by producing new information, and creating alternatives, thus gaining political power vis-àvis the existing gatekeepers. In this case, there was also a media backlash: since the release of the video, criticism has been levelled at IC regarding its actions, agendas, operations and staff. However, at the time, the campaign attracted much attention, may have influenced the debate and power relations in the issue arena and, for a moment, seemed to be accumulating enough power to break into the central hub. This may also have forced the two established human rights NGOs to respond.

\footnotetext{
71 Meriläinen \& Vos, "Human Rights Organizations and Online Agenda Setting” (2011) 16 Corporate Communications, an Int J 293-310; D Davis, A Murdie \& C Garnett Steinmetz, ““"Makers and Shapers”: Human Rights INGOs and Public Opinion” (2012) 34 Human Rights Quarterly 199-224.

72 Conrad Quilty-Harper, “Kony 2012: Stats breakdown of the viral video” (The Telegraph, March 92012)

<http://www.telegraph.co.uk/news/worldnews/joseph-kony/9134431/Kony-2012-Stats-bre

akdown-of-the-viral-video.html\#> Accessed 5 September 2012.

73 E.g. http://edition.cnn.com/search/?query=invisible+children\&x=0\&y=0\&primaryType=mixed\&sortBy=relevance\&intl=true\#\&sortBy=date

e.g. http://www.bbc.co.uk/search/news/?q=invisible\%20 $\%$ children\&video=on\&audio=on\&text=on

e.g. http://search.ft.com/search?queryText=Invisible+children ; e.g. http://yle.fi/uutiset/maailman_lehdet/3348967

e.g. http://www.reuters.com/article/2012/04/21/us-usakony-idUSBRE83K03A20120421

e.g. http://www.hs.fi/kulttuuri/Lapsisotilaiden+vapauttamista+vaativa+dokumentti+levi\%C3\%A4\%C3\%A4+verkossa/a1305557196325

e.g. http://www.spiegel.de/politik/ausland/jagd-auf-rebellenchef-kony-aktivisten-starten-kampagne-gegen-den-schlaechter-von-uganda-a820110.html.

74 K Barzilai-Nahon, “Toward a Theory of Network Gatekeeping: A Framework for Exploring

Information Control” (2008) 59 J of American Society for Info Sci \& Tech 1493-1512.
} 


\section{The Responses}

Just three days after the release of the Kony 2012 video, Amnesty and HRW responded to IC's campaign. The next section summarises and interprets their responses following a chronological timeline to see how the gatekeepers used framing and whether power relations changed over time. In Table 1, the dates and number of responses are presented.

Table 1. The Responses of Amnesty and HRW.

\begin{tabular}{|c|c|c|c|}
\hline \multicolumn{2}{|c|}{ Amnesty } & \multicolumn{2}{|c|}{ HRW } \\
\hline Date & $\begin{array}{l}\text { Number of } \\
\text { responses }\end{array}$ & Date & $\begin{array}{l}\text { Number of } \\
\text { responses }\end{array}$ \\
\hline $8.3^{75}$ & 1 & $9.3^{76}$ & 2 \\
\hline $\begin{array}{l}13.3 \\
77\end{array}$ & 1 & $\begin{array}{l}12.3 \\
78\end{array}$ & 1 \\
\hline $\begin{array}{l}14.3 \\
79\end{array}$ & 1 & $\begin{array}{l}14.3 \\
80\end{array}$ & 2 \\
\hline $\begin{array}{l}18.4 / \\
19.4 \\
81\end{array}$ & $\begin{array}{l}1 \text { (same } \\
\text { post) }\end{array}$ & $\begin{array}{l}15.3 \\
82\end{array}$ & 1 \\
\hline $\begin{array}{l}23.5 \\
83\end{array}$ & 1 & $\begin{array}{l}21.3 \\
84\end{array}$ & 1 \\
\hline $\begin{array}{l}24.5 \\
85\end{array}$ & 1 & $\begin{array}{l}23.3 \\
86\end{array}$ & 1 \\
\hline $\begin{array}{l}29.6 \\
/ 20.7 \\
87\end{array}$ & $\begin{array}{l}1 \text { (same } \\
\text { post) }\end{array}$ & $4.4^{88}$ & 1 \\
\hline
\end{tabular}

75 http://www.amnesty.org/en/news/efforts-arrest-joseph-kony-must-respect-human-rights-2012-03-08

76 http://www.hrw.org/news/2012/03/09/capturing-kony ; http://www.hrw.org/news/2012/03/09/how-catch-joseph-kony

77 https://www.amnesty.org/en/appeals-for-action/Support-UN-role-in-arresting-International-Criminal-Court-fugitives

78 http://www.hrw.org/news/2012/03/12/child-soldiers-worldwide

79 http://www.amnesty.org/en/news/landmark-icc-verdict-over-use-child-soldiers -2012-03-14

80 http://www.hrw.org/news/2012/03/14/icc-landmark-verdict-warning-rights-abusers ; http://www.hrw.org/news/2012/03/14/campaigningaction-joseph-kony-and-lra

81 http://www.amnesty.org/en/library/asset/AFR62/005/2012/en/56c3e218-514d-4e0e-97f4-128d56a864dc/afr620052012en.pdf

http://www.amnesty.org/zh-hant/node/30985

82 http://www.hrw.org/news/2012/03/15/justice-congo

83 http://www.amnesty.org/en/region/uganda/report-2012

84 http://www.hrw.org/news/2012/03/21/qa-joseph-kony-and-lords-resistance-army

85 http://amnesty.org/en/library/asset/POL10/024/2012/en/784820f2-5a3a-4dff-b7b4-b814033b5b9b/pol100242012en.pdf http://www.amnesty.org/en/annual-report/2012/global-update

86 http://www.hrw.org/news/2012/03/23/child-soldiers-worldwide-scourge 


\begin{tabular}{|l|l|l|l|}
\hline $1.7^{89}$ & 1 & $\begin{array}{l}20.4 \\
90\end{array}$ & 3 \\
\hline $\mathbf{n}=$ & $\mathbf{8}$ & $\begin{array}{l}29.6 \\
91\end{array}$ & 1 \\
\hline & & $5.7^{92}$ & 1 \\
\hline & & $9.7^{93}$ & 2 \\
\cline { 3 - 4 } & & $\mathbf{n}=$ & $\mathbf{1 6}$ \\
\cline { 3 - 4 } & & & \\
\hline
\end{tabular}

\section{Results of the Textual Analysis}

Amnesty and HRW responded similarly to IC's agenda. Amnesty published many posts on its main website. Eight were counted as separate posts as they differed in textual content. Compared with Amnesty, HRW was more active with its 16 different online posts. Thus, altogether 24 posts were analysed.

As the first post on 8 March indicates, Amnesty recognised the effect of the Kony 2012 video, giving credit to IC as an issue raiser by stating that the video had generated a massive public response. Amnesty went on to say, however, that the solution to the problem was not for the American armed forces to intervene, as suggested by IC. Amnesty offered its own solutions: capturing Joseph Kony in accord with international law and bringing him to face justice at the ICC, while also including neighbouring African countries in the process. What Amnesty did from the very beginning was to emphasise, in other words, frame, the results of its own years-long research on the topic. Amnesty claimed that although it is good to shine a spotlight on warlords through campaigns such as Kony 2012, other warlords should not be forgotten; they all need to be brought to justice to face charges for diverse crimes, not just the use of child soldiers. One week after the video’s original release, neither IC nor the Kony 2012 video campaign was mentioned; Amnesty referred to IC and the video by saying "recent spotlight”.

\footnotetext{
87 http://www.amnesty.org/en/activism-center http://www.amnesty.org/en/international-justice 
IC was at no time mentioned by Amnesty in news stories during the 18-week monitoring period; instead Amnesty used framing to credit its own research and central position in the human rights network. The only references to IC were in secondary statements, such as references to the Kony 2012 campaign. This testifies to the unwillingness of gatekeepers to link themselves to, and thereby legitimise, less credible actors such as IC and its different approach. Amnesty addressed warlords, the ICC, Joseph Kony and Central Africa, but mostly in the same posts or at least via links to each other. Amnesty also provided links to their own research on Uganda and other matters, as well as links to their social media sites, in line with the multiplatform tactics previously discussed by Meriläinen and Vos. ${ }^{94}$

Unlike Amnesty, HRW provided a direct link to the Kony 2012 video on YouTube in its first post on 9 March. This shows that HRW did credit IC as an issue raiser. Much like Amnesty, HRW credited the video for providing much needed information about Kony and his crimes. Afterwards, however, HRW, like Amnesty, began to use framing to emphasise its own research, not only in Uganda but also in Congo, South Sudan and the Central African Republic. HRW also mentioned how their results were taken directly to policy makers, such as President Obama, thereby framing their research as central to the political debate. Like Amnesty, HRW called for an international response and underlined the role of the ICC along with the UN peacekeepers. HRW did not identify IC as a human rights NGO, but instead called them “a group”, while at the same time emphasising the flaws in IC's campaign, thus placing IC in a different position in the network.

Similarly to Amnesty, HRW appeared to use framing to take over the issue and credit themselves as a central actor in the case of Kony and related issues, rather than providing support for IC's campaign or welcoming the NGO, if not to the central hub as an equal member, then to the network. This supports the notion that gatekeepers act as guardians of the network and their own position in it, and do not willingly co-operate with actors they do not consider credible. Like Amnesty, HRW also linked child soldiers and the warlord Kony with the ICC, and even published a news story on child soldiers worldwide one week after the release of the Kony 2012 video. HRW also, like Amnesty, provided multiple links to their own earlier documents, news and videos. Less than two weeks later, HRW again mentioned IC and the Kony 2012 video, crediting it for raising awareness. HRW stated that while its intentions were commendable and the video was a good first step, the campaign had faults. HRW called for next steps, such as policy changes after the fact rather than just clicking an online "Like" button. Here we again see the trend towards giving IC credit for being an issue raiser, while at the same time emphasising the difference between IC and the work of HRW for real-world solutions.

In addition, just two weeks after the release of the Kony 2012 video, HRW did a Question \& Answer piece about Joseph Kony and the issues related to him. In the Q\&A, HRW credited IC, although without mentioning the NGO by name, and later on in the text claimed that the criticism directed at IC was valid. While providing links to their 
own research, HRW further emphasised that in-depth research was needed as background to influence policy makers. This highlighted, i.e. framed, its central role as a researcher. HRW positioned Joseph Kony and Uganda as only one of many issues needing attention. Moreover, in HRW's letter writing posts that related to Joseph Kony, LRA or warlords and connected violations, IC was not cited as a legitimate actor.

What is interesting is that both Amnesty and HRW raised the human rights violations perpetrated by Ugandan government forces. Both gatekeepers stated that if a lasting solution were to be achieved, violations by government forces must also be investigated by the ICC, an issue that was absent from IC's video.

The NGOs gave credit to other actors to varying degrees. During the 18-week monitoring period, HRW posted letters written by other civil society organisations. HRW did not sign all of these, but believed them to be powerful and thus shared them, while criticising IC at the same time. Amnesty, in turn, gave less credit to other actors, including IC. Unlike Amnesty, HRW did not emphasise its own role in the setting up of the ICC, but rather focused on the last ten years of the ICC's activities, its achievements and failures, and future challenges.

The monitoring period supported the notion that HRW and Amnesty function as the gatekeepers in the human rights network. The gatekeepers gave credit to IC, but only as a less central actor, an issue raiser. Although issue raisers may be important and should be valued, in this case study IC was not credited as an equal member of the human rights network. The reactions from Amnesty and HRW were surprisingly strong, supporting the gatekeeper theory. Amnesty and HRW operated as a central hub, taking control of the agenda and presenting their own framing of the issue to support their views and existing expertise.

\section{Discussion and Conclusions}

This study analysed the responses of two gatekeeper NGOs, Amnesty and HRW, to the online campaign Kony 2012 launched by IC, a newcomer NGO. It sought to find out what, if any, influence, IC's action had on the power relations in the network. In their earlier work, Bob and Carpenter ${ }^{95}$ emphasised the role of gatekeepers in maintaining existing power relations in the network, while a more dynamic picture, in which nongatekeepers may be successful in influencing power relations, has been proposed by Barzilai- Nahon. ${ }^{96}$

The results of the study support the gatekeeper theory, although noting the momentary power of a less central actor as an issue raiser shows the potential of social media, at least in the short term, to change the existing power relations. The gatekeepers reacted to IC and its Kony 2012 campaign by acknowledging the spotlighting of Kony

95 C Bob, The International Struggle for New Human Rights (U of Pennsylvania Press: Pennsylvania Studies in Human Rights, 2009); CR Carpenter, "Setting the Advocacy Agenda: Theorizing Issue Emergence and Nonemergence in Transnational Advocacy Networks” (2007) 51 Int Studies Quarterly 99-120.

96 Barzilai-Nahon, “Toward a Theory of Network Gatekeeping: A Framework for Exploring

Information Control” (2008) 59 J of American Society for Info Sci \& Tech 1493-1512. 
and the popularity of the energetic campaign, but they did not welcome IC into the inner central hub or into the network. Instead, they framed IC and its efforts to catch Joseph Kony as lacking credibility and naïve, whilst framing their own decade-long work on the issue and themselves as more knowledgeable professionals in the human rights network who are able to create real-world solutions. The study shows that in a network not all the actors welcome each other; they may not share information or they may form bi-lateral relationships or alliances. Thus, not all actors equally share power or occupy the same position in the debate in an issue arena, and the network is, therefore, characterised by asymmetrical power relations.

The framing strategy of Amnesty and HWR seemed intended, first, to emphasise their own expertise and long-term work on the issues of Kony, the LRA, Central Africa, child soldiers and prostitution in the area. Secondly, these frames were additionally strengthened by not mentioning IC by name and stressing the lack of real-world solutions in the Kony 2012 campaign. This could be termed expertise framing, indicating that IC was not welcome into the central hub to work on the issue of Kony and related human rights violations. Possibly its approach was not congruent with those of the two gatekeepers and may have been seen as not beneficial to the network in the long term. During the short period in which multiple frames and views were posted on how best to tackle human rights violations, the gatekeepers quickly made sure that their own frames would remain dominant by repeating them and emphasising their own expertise and long-term work on various human rights issues instead of more explicitly confronting the new player. In doing this, Amnesty and HRW accorded IC only limited credit and, by extension, power. The enormous response of both social and traditional media called for the two gatekeepers to react swiftly. This would support the central hub theory ${ }^{97}$ and Pallas and Urpelainen's theory on how well-established actors choose frames and persuade other actors to share and support these frames. ${ }^{98}$ In this case, the central hubs, Amnesty and HRW, strengthened the process by framing themselves as the authorities on the issue and stressing their own advocacy, expertise and organisational power.

This is not to say that well-established actors in the central hub are unwilling to share power. They may wish to avoid legitimising a new actor with a different approach and genuinely feel that their own research and advocacy work is more valuable, for example in educating other stakeholders such as decision-makers and members of the public. $^{99}$ In this way, well-established NGOs who act as gatekeepers tend to reinforce existing power structures in the human rights networks, which may reduce the chances

97 C Bob, The International Struggle for New Human Rights (U of Pennsylvania Press: Pennsylvania Studies in Human Rights, 2009); CR Carpenter, “Setting the Advocacy Agenda: Theorizing Issue Emergence and Nonemergence in Transnational Advocacy Networks” (2007) 51 Int Studies Quarterly 99-120. CR Carpenter, “Setting the Advocacy Agenda: Theorizing Issue Emergence and Nonemergence in Transnational Advocacy Networks” (2007) 51 Int Studies Quarterly 99-120. 98 CL Pallas \& J Urpelainen, “Mission and Interests: The Strategic Formation and Function of North-South NGO Campaigns” (2013) 19 Global Governance: A Rev of Multilateralism \& Int Orgs 401-423, 405.

99 JN Druckman, “On the Limits of Framing Effects: Who Can Frame?” (2001) 63 J of Politics 1041- 1066, 1061. 
that new issues and frames receive attention, fitting Carpenter's and Bob’s ${ }^{100}$ notion of gatekeepers seeking to remain gatekeepers. However, in this case, IC's use of social media made it, at least for a short while, successful in gaining attention, resonating with Barzilai-Nahon's ${ }^{101}$ views on less central actors being able to change power relations. However, this case indicates that for an actor to gain a position in the long term, successful use of social media is not enough. Other factors, such as how well the approach of the new actor fits the existing values in the network, are also important. Above all, this case shows that, for new actors, social media has the potential to lower the entry threshold into an arena. The results point to a need for a re-evaluation of the gatekeeper theory in light of the emergence of social media.

For a brief moment, the Kony 2012 campaign became a salient issue in the contemporary human rights debate. How was IC, despite being relatively unknown, able to do this? IC reframed an old issue and combined a lively video, in which the person of Kony was central, with multiplatform tactics on both social media sites and their own main website to draw attention, particularly of young people, to that issue. ${ }^{102}$ IC urged its publics to use online communication, together with demonstrations and letter-writing campaigns, to create change. IC framed getting involved as being easy. As stated by Pepper, many young people who watched the video wanted to learn more. ${ }^{103}$ The massive online public response generated by Kony 2012 in turn caused the traditional media pick up the story. Although much was said in the original Kony 2012 video about IC, little information was offered about the work being done on the ground in Uganda. IC was successful in capitalising on its value frames to which its young audience responded strongly. However, IC did not offer detailed suggestions as to how the human rights violations of using child soldiers and prostitution might be tackled, but instead saw US military action against the LRA as the solution to solving human rights violations in Uganda and other African states, an option opposed by both Amnesty and HRW. Deployment of US military advisors in African states could mean that civilians would pay the price, as possible failure could lead to retaliation against them. ${ }^{104}$ Burgess $^{105}$ also questioned whether western involvement alone is the answer to Uganda's problems and proposed a multi-actor approach to tackle human rights violations in the area, including Uganda and neighbouring regions. In similar vein,

100 C Bob, The International Struggle for New Human Rights (U of Pennsylvania Press: Pennsylvania Studies in Human Rights, 2009); CR Carpenter, “Setting the Advocacy Agenda: Theorizing Issue Emergence and Nonemergence in Transnational Advocacy Networks” (2007) 51 Int Studies Quarterly 99-120.

101 K Barzilai-Nahon, “Toward a Theory of Network Gatekeeping: A Framework for Exploring Information Control” (2008) $59 \mathrm{~J}$ of American Society for Info Sci \& Tech 1493-1512.

102 Meriläinen \& Vos, “Human Rights Organizations and Online Agenda Setting” (2011) 16 Corporate Communications, an Int J 293-310.

103 S Pepper, “Invisible Children and the Cyberactivist Spectator” (2009) 6 Nebula 40-55. 104 See M Schomerus, “They Forgot What they Came For: Uganda‘s army in Sudan” (2012) 6 J of Eastern African Studies 124-153; RR Atkinson, P Lancaster, L Cakaj \& G Lacaille, “Do No Harm: Assessing a Military Approach to the Lord’s Resistance Army” (2012) 6 J of Eastern African Studies 371-382.

105 Burges, “Efforts at Peace: Building a United Uganda” (University of Tennessee Honors Thesis Projects)

<http://trace.tennessee.edu/utk_chanhonoproj/1157> Accessed 17 August 2012. 
Pallas, Fletcher and Han stated that “The Invisible Children’s Kony 2012 campaign has spent millions of dollars exciting public interest in an issue that was already largely resolved, while current human rights abuses are ignored". ${ }^{106}$ Moreover, according to Finnström, the Kony 2012 campaign was dangerous and simplified the Ugandan situation, and also dehistoricised reality. ${ }^{107}$ By laying all the blame on Kony while disregarding the underlying problems of the war-torn continent, IC creates a false reality where issues and solutions are seen as black and white.

In this study, Amnesty and HRW acted as gatekeepers in the international human rights debate, and IC as a newer, less central actor. The results showed that all three human rights NGOs used value framing as well as naming and shaming framing, clearly labelling the good and bad guys. Based on the overwhelming public response to its Kony 2012 campaign, IC and its supporters may have believed that it had found the solution to the problem of catching Joseph Kony and stopping human rights violations in Uganda, while both Amnesty and HRW followed a different course, emphasising their own expertise on the matter. Although IC simplified the issue of child soldiers and war crimes connected to Joseph Kony and LRA, while not providing much of a realworld solution to human rights violations, IC was successful in bringing the issue to a worldwide audience by framing it as salient for a young audience familiar with online visuals, and thus easily reached by this online campaign. The findings indicate that although IC, by bringing a fresh perspective to issues connected to warlord Joseph Kony, was able to force the central hub also to address the campaign, the central human rights actors sought to retain their gatekeeping role and only shared power to a limited degree. It should also be noted that the issue remained salient for longer than the four to six weeks suggested by Winter and Eyal. ${ }^{108}$ At the end of the 18-week monitoring period, the issue of Joseph Kony had almost completely faded from the news posts of the main websites, and IC was no longer visible in the issue arenas monitored, while human rights violations in Uganda were no closer to being solved.

As explained in the theoretical section, framing is often designed to appeal to the values and beliefs of actors by emphasising certain aspects or attributes of an issue, in pursuit of making them salient. When actors choose to advocate a certain human rights issue by framing it in a particular way, some other issues are left without attention, as attention to issues can be considered a zero-sum game. Cost-benefit analyses by actors in issue arenas guide their strategies and interactions which, while targeted at contributing to solving societal problems, are at the same time also targeted at obtaining or maintaining power and a central position in the relevant networks.

The results of this study suggest that both Amnesty and HRW saw it as costbeneficial to address the issue of Kony 2012, as the issue was regarded as salient on

106 CL Pallas, K Fletcher \& B Han “How Do Campaigners Choose Their Targets? Exploring Cost-Benefit Analysis among Nongovernmental Organizations” (2012) Presented at International Studies Association Annual Convention, San Diego, April 1-4, 2. 107 S Finnström, ““KONY 2012” and the Magic of International Relations” (2012) <http://www.e-ir.info/2012/03/15/kony2012-and-the-magic-of-international-relations/> Accessed 16 August 2012. 108 JP Winter \& CH Eyal, “Agenda Setting for the Civil Rights Issue” (1981) 45 Public Opinion Quarterly 376-383. 
multiple issue arenas both in online and traditional media, while at the same time retaining their gatekeeper role.

Human rights NGOs investigate and report human rights violations domestically and internationally. They promote activism and influence decision-making. Due to the selective realities of issue arenas and their capacity, not all issues of current interest can be accorded the same amount of attention. Nevertheless, human rights issues need to be regarded as salient in order for debate to happen and decisions to be made. Much like IC, other human rights NGOs use framing to draw attention to certain human rights issues at a certain moment in time. They also use framing to maintain organisational power in human rights networks, as this case study illustrated. Framing is specific to the actor, arena, issue and time. IC was able to break into the human rights network by means of framing, but was met with media criticism and counter-framing by the two gatekeeper NGOs who did not deem the actor credible.

To summarise, this study started out on the theoretical premise that issue arena debate can be explained with reference to issue arenas and power relations, gatekeeper theory and framing. The actors involved in the issue arena debate on human rights issues operate in networks to find solutions to social problems and define policy and legislative norms both domestically and internationally. Aside from asserting control over the debate, the power of gatekeepers such as Amnesty and HRW may also be visible in terms of resources, such as funding and high quality research, as well as more educated and culturally knowledgeable staff. The relations in the network may change when a new actor, such as IC, introduces a new issue based on new information or, in this case, an old issue in a new way, with a new frame. If the issue receives sufficient attention in various media and among other actors, then the gatekeepers must address it. Outcomes can vary, from accepting the new actor into the central hub, through accepting the issue with its frames, accepting the issue but in terms of the central hub's own frame, to discrediting the new actor by framing that actor negatively and emphasising the central hub's own activities with respect to the issue. In the social media era it is to be expected that power in networks can change relatively fast. New actors may introduce new issues and frames and may as a result become active actors in the network or even gatekeepers themselves, e.g. in a situation where attention shifts from one issue to another and the power structure is disrupted. Gatekeepers will then need to be active if they wish to maintain their position. However, for the human rights debate as such it may be a favourable to evaluate new input by potential future actors in the arena, as they may contribute fresh ideas to human rights issues and so make them salient.

Invisible Children was able to make an already known, but at that moment nontopical, issue salient once again by means of framing, but in the end it was overpowered by media criticism and re-framing by the actors in the central hub. The gatekeepers, Amnesty and HRW, reacted by taking over the issue and framing the new NGO as less credible. Both Amnesty and HRW emphasised their own work and expertise by using framing to give valuable meaning and credibility to the work and to themselves, rather than collaborating with IC. The results of this study demonstrate that human rights NGOs compete for positions inside the network. Although the issues they focus on are 
sensitive and their goals are based on moral philosophy, actors in the human rights network nevertheless calculate costs, benefits and losses in efforts to protect their positions, and hence new actors are not unconditionally welcomed into the issue arenas.

This study has some limitations. The study period, starting with the release of the Kony 2012 video and continuing for 18 weeks, was chosen to allow for observation of possible reframing during the campaign and the reactions to a new actor's agenda of the existing human rights gatekeepers. However, it is possible that long-lasting effects on the salience of the issue outside this period may also have occurred. Moreover, the reaction of the traditional media to the Kony 2012 campaign might also have had an influence on the responses by Amnesty and HRW, since agenda setting and framing by multiple actors is always connected. ${ }^{109}$ Interference between frames and the transfer of issues between the traditional news media and online media may be addressed in later studies. 